\title{
Effect of a conventional energy-restricted modified diet with or without meal replacement on weight loss and cardiometabolic risk profile in overweight women
}

\author{
Christine E Metzner ${ }^{1,2^{*}}$, Anke Folberth-Vögele ${ }^{1,3}$, Norman Bitterlich ${ }^{4}$, Martin Lemperle ${ }^{3}$, Sandy Schäfer ${ }^{1,5}$,
} Birgit Alteheld ${ }^{6}$, Peter Stehle ${ }^{6}$ and Roswitha Siener ${ }^{7}$

\begin{abstract}
Background: Abdominal obesity, atherogenic dyslipidemia and hypertension are essential risk factors for cardiovascular diseases. Several studies showed favorable effects of weight loss in overweight subjects on cardiometabolic risk profile.
\end{abstract}

Methods: This open-label, randomized, controlled study investigated the effect of an energy-restricted modified diet with (MR) or without meal replacements for weight control (C) on weight loss, body composition and cardiometabolic risk profile in overweight women. Of 105 randomized participants, 87 were eligible for per protocol analysis. Anthropometric, clinical, blood, 24 h-urine parameters and dietary intake were assessed at baseline and after 12 weeks.

Results: Dietary intervention resulted in a significant weight loss in both groups (MR: $-5.98 \pm 2.82 \mathrm{~kg} ; \mathrm{p}<0.001, \mathrm{C}$ : $-4.84 \pm 3.54 \mathrm{~kg} ; \mathrm{p}<0.001$ ). However, the rate of responder (weight loss $>5 \%$ ) was higher in MR $(77 \%)$ versus $C$ group (50\%) ( $p=0.010)$. A significant reduction in waist circumference (WC) and body fat mass (BFM) was observed in both groups. Body cell mass (BCM) and lean body mass (LBM) decreased, while percentage of BCM of body weight increased in MR more than in $C$ group. Systolic and diastolic blood pressure (BP) significantly decreased and to a similar extent in both groups. Total cholesterol (TC), LDL-C but also HDL-C declined significantly in both groups, while no change occurred in triglycerides.

Conclusions: Both dietary intervention strategies had a similar effect on weight loss and body fat distribution, but rate of responder was significantly higher in MR group. Systolic BP decreased to a similar extent in both groups. Cardiometabolic risk profile improved only partly in both groups.

\section{Introduction}

The rising prevalence of obesity is considered a major cause for disorders such as type 2 diabetes (DM2) and cardiovascular diseases $[1,2]$. Type of body fat distribution seems to play a crucial role in the pathogenesis of obesity-related diseases. Due to its higher endocrine and metabolic activity compared to subcutaneous adipose tissue, visceral adipose tissue is regarded as a predictor

\footnotetext{
* Correspondence: christine.metzner@rwth-aachen.de

'Bonn Education Association for Dietetics r. A., Fürst-Pückler-Str. 44, D-50935 Cologne, Germany

Full list of author information is available at the end of the article
}

of cardiometabolic risk factor levels [2-6]. Abdominal obesity is strongly correlated with visceral adipose tissue, clinically represented by the measurement of waist circumference (WC) [7]. A population-based cohort study of diabetes revealed that a larger waist circumference is associated with a higher risk of DM2, especially in women, whereas larger hip and thigh circumferences are clearly associated with a lower risk of diabetes [8].

The widespread lipid disorder in visceral obesity, insulin resistance and metabolic syndrome is atherogenic dyslipidemia, which is characterized by triad of elevated serum triglycerides (TG), low HDL-cholesterol (HDL-C)

\section{() Biomed Central}


and small LDL-C particles [3]. Several studies showed favorable effects of visceral weight loss on serum TG in overweight subjects $[4,9,10]$.

The question is whether the achieved weight loss alone is responsible for the reduction in blood pressure. Besides weight loss, mental stress reduction, dietary sodium restriction, and an increased intake of dietary flavanoids are suggested to reduce blood pressure [11-13]. Weight loss can be achieved by a conventional structured energy-restricted modified diet alone or in combination with meal replacements for weight control. Recent reports indicated that such meal replacements coupled with a low-calorie diet can offer an effective option for weight reduction and improvements in metabolic risk factors in overweight patients [14-16]. Therefore, aim of this prospective randomized study was to evaluate whether a diet with meal replacements (MR) can be as effective as a conventional energy-restricted modified diet (control diet, C) on weight loss, body composition and cardiometabolic risk profile in overweight women.

\section{Methods}

\section{Participants}

Overweight women were recruited from two outpatient centers for nutrition education in Frankfurt/M and Berlin, Germany. Women aged between 18 and 60 years, BMI between 27.0 and $34.9 \mathrm{~kg} / \mathrm{m}^{2}$ and with one of the following blood lipids were included into the study: total cholesterol $(\mathrm{TC}) \geq 200 \mathrm{mg} / \mathrm{dL}$, LDL-cholesterol (LDL-C) $\geq 175 \mathrm{mg} / \mathrm{dL}, \mathrm{HDL}-\mathrm{C} \leq 50 \mathrm{mg} / \mathrm{dL}$, TG $150-400 \mathrm{mg} / \mathrm{dL}$. Exclusion criteria were lactose or protein intolerance, hypo- or hyperthyroidism, pharmacological treatment of diabetes, intake of vitamins or mineral supplements, anticoagulants, cardiac pacemaker and contraindications to exercise. One hundred and thirteen subjects were screened (Figure 1). The study was approved by the ethics committees of the Chamber of Physicians of the German federal states of Hessen and Berlin. Informed consent was obtained from each participant prior to study onset.

\section{Study design}

In a 12-week open-label, randomized, controlled intervention trial, subjects were randomly assigned to the $\mathrm{MR}$ or the $\mathrm{C}$ group, respectively, by a computer-generated identification number in order of recruitment. Blood samples, dietary records, clinical and biochemical data were collected at baseline and repeated 12 weeks after dietary intervention. Primary end point of the study was weight loss. The planned sample size of 44 subjects per group, excluding drop-out rate, was based on a power of $80 \%$ to detect a difference of at least 2.0 $\pm 3.0 \mathrm{~kg}($ mean $\pm \mathrm{SD})$ between both groups at a level of significance of $\alpha=0.05$.

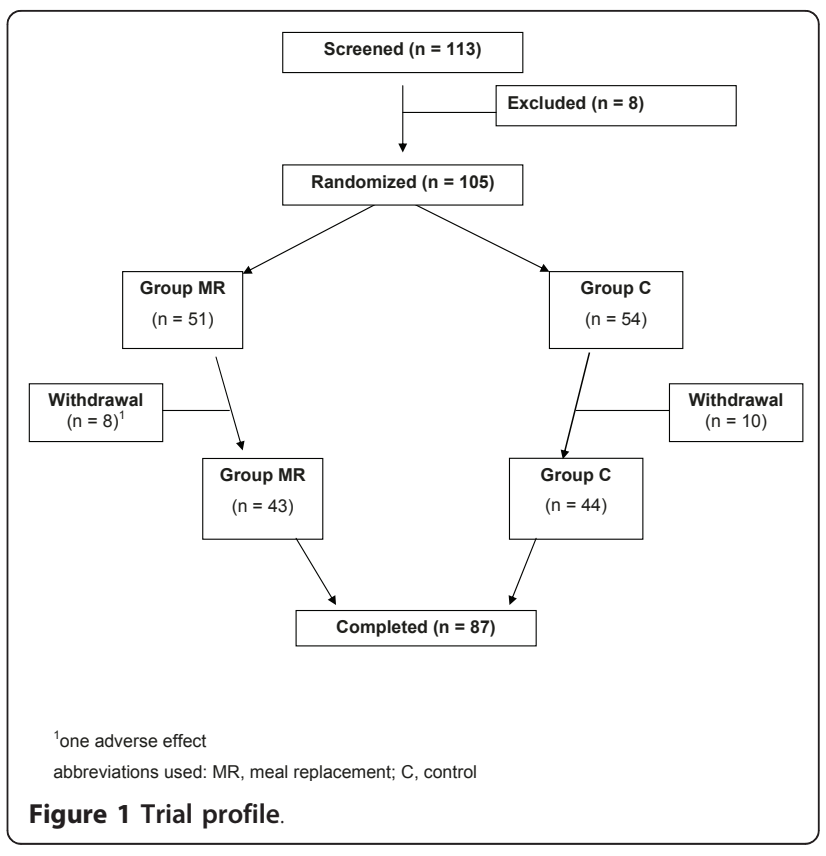

Both dietary intervention groups were instructed to follow an energy-restricted diet of approximately 1200 $\mathrm{kcal} / \mathrm{d}$. Three meals (breakfast, lunch, and dinner) were recommended. The food choice was based on vegetables, fruits, whole grain cereal and low-fat dairy products $(1.5 \%$ fat). The MR group was advised to replace two meals, i.e. breakfast and dinner, every day with two MR shakes, soups or bars (FormMed HealthCare AG, Frankfurt/M, Germany) and to prepare their own lunch. The energy per serving of the MR meal is shown in Table 1. Each MR represented a balanced diet product for weight reduction according to article 14a of the dietary regulation issued by the German Federal Ministry of Food, Agriculture and Consumer Protection, based on Commission Directive 1996/8/EC of 26 February 1996. The $\mathrm{C}$ group was advised to follow a conventional energy-restricted modified diet with $15-20 \%$ of energy intake in the form of protein, 50-55\% of energy intake in the form of carbohydrates and approximately $30 \%$ of energy intake in the form of fat according to previous studies [15,17].

During a 12-week intervention period all participants attended ten group training sessions (eight to ten women per class) and four face-to-face visits for nutrition education. All participants received instruction manuals that included a sample meal plan, recipes and information regarding physical activity. Group training lasted one hour per session. Group training sessions were held separately for each group by a nutrition advisor. Topics of the structured sessions included practical knowledge of food, portion sizes and meal frequency with the aim of changing dietary behavior and lifestyle. 
Table 1 Daily dietary intake with meal replacements (per serving size)

\begin{tabular}{llll}
\hline & Shake & Soup & Bar \\
\hline Energy (kcal) & 205 & 200 & 218 \\
Protein (g) & 19 & 21.9 & 17.2 \\
Carbohydrates (g) & 16.9 & 12.9 & 27.0 \\
Fat (g) & 5.9 & 6.6 & 6.8 \\
Fatty acids & & & \\
SAFA (g) & 2.6 & 0.9 & 2.2 \\
LA (g) & 1.0 & 3.1 & 2.2 \\
MUFA (g) & 1.1 & 1.35 & 2.4 \\
Dietary fibre (g) & 2.4 & 1.5 & 3.1
\end{tabular}

\begin{tabular}{|c|c|c|c|}
\hline \multicolumn{4}{|l|}{ Minerals } \\
\hline Sodium (mg) & 180 & 900 & 183 \\
\hline Potassium (mg) & 510 & 605 & 539 \\
\hline Magnesium (mg) & 200 & 61 & 82 \\
\hline Calcium (mg) & 525 & 300 & 329 \\
\hline Phosphate (mg) & 357 & 208 & 279 \\
\hline Iron (mg) & 7.5 & 4.9 & 8 \\
\hline Zinc (mg) & 5.0 & 3.0 & 7.4 \\
\hline Manganese (mg) & 0.6 & 0.4 & 1.5 \\
\hline Copper (mg) & 0.7 & 0.4 & 1.0 \\
\hline lodine $(\mu g)$ & 75 & 41 & 75 \\
\hline Selenium ( $\mu \mathrm{g})$ & 36 & 16.5 & 27 \\
\hline \multicolumn{4}{|l|}{ Vitamins } \\
\hline Vitamin A $(\mu \mathrm{g})$ & 400 & 210 & 600 \\
\hline Vitamin B1 (mg) & 0.7 & 0.3 & 0.8 \\
\hline Vitamin B2 (mg) & 1.2 & 0.5 & 0.9 \\
\hline Vitamin B6 (mg) & 1.0 & 0.5 & 1.1 \\
\hline Vitamin B12 ( $\mu \mathrm{g})$ & 1.5 & 0.4 & 1.7 \\
\hline Vitamin C (mg) & 45 & 13.5 & 34 \\
\hline Vitamin D $(\mu \mathrm{g})$ & 2.5 & 1.5 & 2.9 \\
\hline Vitamin E (mg) & 10 & 3.0 & 11.5 \\
\hline Biotin $(\mu g)$ & 75 & 4.5 & 86 \\
\hline Folic acid $(\mu \mathrm{g})$ & 150 & 60 & 115 \\
\hline Nicotinic acid (mg) & 12 & 5.4 & 10 \\
\hline Pantothenic acid (mg) & 3.0 & 0.9 & 5.7 \\
\hline
\end{tabular}

The average duration of the monthly face-to-face visits was 25 minutes (range 10-40 minutes).

At baseline women were instructed on food selection, portion size estimation and accurate recording of dietary intakes. Three-day food records were documented at baseline and after the 12-week intervention. Dietary records were reviewed with each study participant and analyzed using PRODI 5.3 software (WVG, Stuttgart, Germany).

Body weight $(\mathrm{kg})$ and height $(\mathrm{cm})$ were measured. WC, HC and thigh circumference was determined via flexible tape. The goal to achieve $>5 \%$ weight loss was a targeted value. Body fat mass (BFM), body fat (\%), body cell mass (BCM), and lean body mass (LBM) were determined by bioelectrical impedance analysis (BIA) with biaform ${ }^{\circledR}$ software version 2.2 under standardized conditions [17]. Blood pressure (BP) was measured under standardized conditions after a $10 \mathrm{~min}$. resting period. Anthropometric measurements and venous blood sampling were performed in the morning after an overnight fasting period of at least $12 \mathrm{~h}$. Due to analysis of serum cortisol, blood samples were taken at 9:00 a.m. At baseline and after the 12-week dietary intervention, 24-hour urines were collected.

\section{Laboratory methods}

Analyses of serum glucose (hexokinase method), uric acid (uricase-PAP method), gamma-glutamyltransferase (kinetic color test IFCC), total cholesterol (TC) (CHODPAP method), LDL-C and HDL-C (enzymatic color test), TG (GPO-PAP method) on Olympus 600 analyzer, homocysteine, folic acid and cortisol (chemiluminiscence method) on ADVIAR Centaur analyzer and glycated hemoglobin (HbA1c) (HPLC) on Biorad Variant II analyzer were conducted by the medical laboratory Potsdam, Germany.

Determination of the total antioxidative capacity (TAC) was performed by the reaction of antioxidants in the sample with a defined amount of exogenously provided hydrogen peroxide $\left(\mathrm{H}_{2} \mathrm{O}_{2}\right)$. The antioxidants in the sample eliminate a certain amount of the provided hydrogen peroxide. The residual $\mathrm{H}_{2} \mathrm{O}_{2}$ is determined photometrically by an enzymatic reaction which involves the conversion of TMB to a colored product.

Analysis of $24 \mathrm{~h}$ urinary sodium excretion (ion sensitive electrode (ISE)) was performed at the laboratory of Medical Nutrition Science, Department of Urology, University of Bonn, Germany.

Laboratory quality certification was available for each parameter except for homocysteine, folic acid and TAC.

\section{Statistical methods}

Statistical comparisons between groups were performed using the nonparametric Mann-Whitney U test for unpaired data. Pre-post intervention changes were analyzed via non-parametric Wilcoxon test. All statistical tests were two-sided. Differences were considered significant at $\mathrm{p}<0.05$. Data are reported as mean \pm standard deviation (SD). ANCOVA including use of weight change and age as covariates was used to control for the potential confounder of systolic BP. Data analysis was performed based on the per protocol population and by using SPSS $^{\circledR}$ for Windows (version 19.0).

\section{Results}

\section{Participants}

A total of 105 overweight women were randomized, of whom 87 were eligible for per protocol (PP) analysis 
(Figure 1). Twelve women discontinued the study: one due to adverse effects (diarrhea) in the MR group and 11 for personal reasons (four women in the MR and seven women in the $\mathrm{C}$ group). Additionally, six women had to be excluded from analysis due to protocol violations. Meal replacements were well tolerated by the patients.

No differences were observed at baseline between both groups regarding anthropometric, clinical and biochemical parameters. Fifty-nine women $(67.8 \%)$ had obesity stage I (Table 2). The ratio of obesity stage I (30.0-34.9 $\left.\mathrm{kg} / \mathrm{m}^{2}\right)$ to preobesity $\left(27.0-29.9 \mathrm{~kg} / \mathrm{m}^{2}\right)$ was approximately $2: 1$ in both groups. Abdominal adipose tissue distribution type (WC $>88 \mathrm{~cm}$ ) did not differ between the MR and the C group. Systolic blood pressure (130/ $80 \mathrm{mmHg}$ ) was slightly above the cutoff in the MR group [3].

\section{Anthropometric and clinical characteristics}

Dietary intervention resulted in a significant weight loss in both groups, without significant difference between the $M R$ and the $C$ group (Table 3 ). However, relative weight loss in the MR group was higher compared to the $C$ group ( $\mathrm{p}=0.048)$. Moreover, the rate of responder ( $>5 \%$ weight loss) was higher in the MR group (33

Table 2 Baseline characteristics of overweight women in the meal replacement (MR) and control group (C), respectively

\begin{tabular}{lccc}
\hline & $\begin{array}{c}\text { MR } \\
(\mathbf{n}=\mathbf{4 3}) \\
\text { Mean } \pm \text { SD }\end{array}$ & $\begin{array}{c}\text { C } \\
\text { Mean } \pm \text { SD }\end{array}$ & $\begin{array}{c}\text { MR vs C } \\
\text { P }\end{array}$ \\
\hline Age (years) & $49.8 \pm 11.7$ & $49.6 \pm 11.0$ & $0.776^{\mathrm{a}}$ \\
\hline Weight $(\mathrm{kg})$ & $83.9 \pm 8.8$ & $84.1 \pm 8.3$ & $0.946^{\mathrm{a}}$ \\
\hline Height $(\mathrm{cm})$ & $163.8 \pm 5.9$ & $164.0 \pm 5.8$ & $0.909^{\mathrm{a}}$ \\
\hline BMl $\left(\mathrm{kg} / \mathrm{m}^{2}\right)$ & $31.2 \pm 2.3$ & $31.2 \pm 2.1$ & $0.912^{\mathrm{a}}$ \\
BMl $27.0-29.9 \mathrm{~kg} / \mathrm{m}^{2}(\mathrm{n})$ & $14(32.6 \%)$ & $14(31.8 \%)$ & $0.941^{\mathrm{b}}$ \\
BMl $30.0-34.9 \mathrm{~kg} / \mathrm{m}^{2}(\mathrm{n})$ & $29(67.4 \%)$ & $30(68.2 \%)$ & $0.941^{\mathrm{b}}$ \\
\hline WC $(\mathrm{cm})$ & $93.9 \pm 7.2$ & $94.9 \pm 6.1$ & $0.491^{\mathrm{a}}$ \\
WC $80-88 \mathrm{~cm}(\mathrm{n})$ & $12(27.9 \%)$ & $7(15.9 \%)$ & $0.176^{\mathrm{b}}$ \\
WC $>88 \mathrm{~cm}(\mathrm{n})$ & $31(72.1 \%)$ & $37(84.1 \%)$ & $0.176^{\mathrm{b}}$ \\
\hline BP systolic $(\mathrm{mmHg})$ & $131.2 \pm 17.4$ & $128.0 \pm 19.7$ & $0.185^{\mathrm{a}}$ \\
BP systolic $\geq 130 \mathrm{mmHg}(\mathrm{n})$ & $27(62.8 \%)$ & $22(50.0 \%)$ & $0.229^{\mathrm{b}}$ \\
\hline BP diastolic $(\mathrm{mmHg})$ & $80.8 \pm 9.6$ & $79.8 \pm 9.0$ & $0.321^{\mathrm{a}}$ \\
BP diastolic $\geq 85 \mathrm{mmHg}(\mathrm{n})$ & $16(37.2 \%)$ & $11(25.0 \%)$ & $0.218^{\mathrm{b}}$ \\
\hline Heart rate $(1 / \mathrm{min})$ & $76.6 \pm 10.6$ & $77.8 \pm 10.8$ & $0.792^{\mathrm{a}}$ \\
Heart rate $>70 / \mathrm{min}(\mathrm{n})$ & $33(76.7 \%)$ & $34(77.3 \%)$ & $0.953^{\mathrm{b}}$ \\
\hline Oral contraceptives $(\mathrm{n})$ & $5(11.6 \%)$ & $3(6.8 \%)$ & $0.438^{\mathrm{b}}$ \\
\hline Smokers $(\mathrm{n})$ & $7(16.3 \%)$ & $9(20.5 \%)$ & $0.615^{\mathrm{b}}$ \\
\hline
\end{tabular}

abbreviations used: BMI, body mass index; BP, blood pressure; WC, waist circumference

aMann-Whitney-U-test

${ }^{\mathrm{b}} \mathrm{Chi}{ }^{2}$-Test women, $77 \%$ ) versus the $\mathrm{C}$ group (22 women, 50\%) after the 12-week dietary intervention $(\mathrm{p}=0.010)$ (Table 4$)$. While women with WC $\leq 88 \mathrm{~cm}$ ( $21.8 \%$ in both groups) lost significantly more weight in the MR group (MR: $5.98 \pm 2.28 \mathrm{~kg}, \mathrm{C}:-0.96 \pm 2.29 \mathrm{~kg} ; \mathrm{p}=0.002$ ), no significant difference in weight change was observed in women with WC > $88 \mathrm{~cm}(\mathrm{MR}:-5.98 \pm 3.04 \mathrm{~kg}$, C: $5.57 \pm 3.25 \mathrm{~kg} ; \mathrm{p}=0.506)$.

Dietary intervention significantly reduced mean BMI from obesity stage I to preobesity in both groups (Table 3). Correspondingly, WC and waist-to-height ratio (WHtR) significantly decreased to a similar extent. After the 12-week dietary intervention, mean WC was below the cutoff of $88 \mathrm{~cm}$ only in the MR group [3]. Within group analysis revealed a significant reduction in BFM, body fat (\%), BCM, and LBM in both groups. After the 12-week dietary intervention, mean systolic and diastolic $\mathrm{BP}$ were within the normal range.

\section{Clinical chemistry and biochemical characteristics}

After the 12-week dietary intervention TC, LDL-C but also HDL-C significantly decreased in both groups, without significant differences between the groups (Table 5). No change was observed in serum TG, glucose and uric acid within and between groups during intervention. Serum homocysteine concentration increased significantly only in the $\mathrm{C}$ group, but this was without clinical relevance. Serum folic acid concentration increased significantly only in the MR group. Serum cortisol concentration and TAC remained unchanged during the intervention period. GGT activity decreased significantly in both groups to a similar extent.

\section{Cardiometabolic risk profile}

Table 4 reflects results related to the cardiometabolic risk profile. The total number of subjects classified with atherogenic dyslipidemia [3] did not reduce significantly during the study. After the 12-week dietary intervention hypertriglyceridemic waist phenotype, i.e. WC $>88 \mathrm{~cm}$ and TG $\geq 150 \mathrm{mg} / \mathrm{dL}$ [18], decreased by $42 \%$ in the MR group and by $50 \%$ in the $C$ group.

\section{Dietary intake}

At baseline, the reported energy intake was similar in both groups (MR: $1574 \pm 408 \mathrm{kcal} / \mathrm{d}$; C: $1683 \pm 414$ $\mathrm{kcal} / \mathrm{d}$ ). After the 12-week intervention energy intake was significantly reduced within each group but not between both groups (MR: $1268 \pm 306 \mathrm{kcal} / \mathrm{d}$; C: $1406 \pm$ $392 \mathrm{kcal} / \mathrm{d})$. The calculated energy expenditure estimated with Harris-Benedict equation [19] at a physical activity level (PAL) of 1.6 differed from these data in both groups at baseline (MR group: $2356 \pm 191 \mathrm{kcal} / \mathrm{d}$ C group: $2378 \pm 163 \mathrm{kcal} / \mathrm{d}$ ) and therefore suggested 
Table 3 Anthropometric and clinical characteristics in overweight women at baseline and after dietary intervention

\begin{tabular}{|c|c|c|c|c|c|c|c|}
\hline & & $\begin{array}{c}M R(n=43) \\
\text { Mean } \pm \text { SD }\end{array}$ & & & $\begin{array}{c}C(n=44) \\
\text { Mean } \pm S D\end{array}$ & & MR vs $C$ \\
\hline & Baseline & Week 12 & Difference & Baseline & Week 12 & Difference & $P^{a}$ \\
\hline Weight (kg) & $83.9 \pm 8.8$ & $78.0 \pm 9.2^{* *}$ & $-5.98 \pm 2.82$ & $84.1 \pm 8.3$ & $79.3 \pm 7.3^{* *}$ & $-4.84 \pm 3.54$ & 0.075 \\
\hline Relative weight loss (\%) & $100 \pm 0$ & $92.8 \pm 3.3^{* *}$ & $-7.19 \pm 3.25$ & $100 \pm 0$ & $94.4 \pm 4^{* *}$ & $-5.60 \pm 4.02$ & 0.048 \\
\hline $\mathrm{BMI}\left(\mathrm{kg} / \mathrm{m}^{2}\right)$ & $31.2 \pm 2.3$ & $29.0 \pm 2.6^{* *}$ & $-2.24 \pm 1.02$ & $31.2 \pm 2.1$ & $29.4 \pm 1.9 * *$ & $-1.79 \pm 1.31$ & 0.075 \\
\hline$W C(\mathrm{~cm})$ & $93.9 \pm 7.2$ & $87.4 \pm 7.6^{* *}$ & $-6.55 \pm 3.91$ & $94.9 \pm 6.1$ & $89.6 \pm 6.3^{* *}$ & -5.304 .27 & 0.094 \\
\hline $\mathrm{WHtR}$ & $\begin{array}{c}0.574 \\
\pm 0.043 \\
\end{array}$ & $\begin{array}{c}0.534 \\
\pm 0.047^{* *} \\
\end{array}$ & $\begin{array}{c}0.040 \\
\pm 0.024 \\
\end{array}$ & $\begin{array}{c}0.579 \\
\pm 0.040 \\
\end{array}$ & $\begin{array}{c}0.547 \\
\pm 0.045^{* *} \\
\end{array}$ & $\begin{array}{c}0.032 \\
\pm 0.026 \\
\end{array}$ & 0.092 \\
\hline $\mathrm{HC}(\mathrm{cm})^{\mathrm{b}}$ & $\begin{array}{c}114.2 \pm 6.4 \\
(n=26)\end{array}$ & $108.5 \pm 6.0$ & $-5.71 \pm 2.34$ & $\begin{array}{c}114.3 \pm 6.0 \\
(\mathrm{n}=28)\end{array}$ & $109.4 \pm 6.5$ & $-4.93 \pm 3.45$ & 0.565 \\
\hline$\overline{W H R^{b}}$ & $\begin{array}{c}0.83 \pm 0.06 \\
(n=26)\end{array}$ & $0.82 \pm 0.05$ & $-0.01 \pm 0.03$ & $\begin{array}{c}0.84 \pm 0.05 \\
(n=28)\end{array}$ & $0.84 \pm 0.06$ & $0.00 \pm 0.03$ & 0.350 \\
\hline Thigh circumference $(\mathrm{cm})^{b}$ & $\begin{array}{c}64.1 \pm 5.0 \\
(n=35)\end{array}$ & $60.8 \pm 5.1$ & $-3.33 \pm 2.10$ & $\begin{array}{c}64.1 \pm 4.6 \\
(n=38)\end{array}$ & $61.5 \pm 5.0$ & $-2.59 \pm 2.35$ & 0.158 \\
\hline BFM (kg) & $36.1 \pm 6.3$ & $31.4 \pm 6.4^{* *}$ & $-4.69 \pm 2.31$ & $36.6 \pm 6.0$ & $32.6 \pm 5,2^{* *}$ & $-3.98 \pm 2.53$ & 0.144 \\
\hline Body fat (\%) & $42.7 \pm 3.8$ & $39.9 \pm 4.3^{* *}$ & $-2.79 \pm 1.79$ & $43.3 \pm 3.6$ & $41.0 \pm 3.6^{*}$ & $-2.33 \pm 1.51$ & 0.191 \\
\hline $\mathrm{BCM}(\mathrm{kg})$ & $25.7 \pm 2.5$ & $24.8 \pm 2.6^{* *}$ & $-0.93 \pm 0.80$ & $25.7 \pm 2.3$ & $24.7 \pm 2.0^{* *}$ & $-0.98 \pm 0.98$ & 0.760 \\
\hline $\mathrm{BCM}(\%)$ & $30.8 \pm 2.9$ & $32.0 \pm 3.1^{* *}$ & $1.19 \pm 1.24$ & $30.7 \pm 3.0$ & $31.3 \pm 2.9^{*}$ & $0.62 \pm 1.17$ & 0.054 \\
\hline LBM (kg) & $48.1 \pm 3.8$ & $46.8 \pm 3.9^{* *}$ & $-1.30 \pm 1.40$ & $47.7 \pm 3.8$ & $46.9 \pm 3.3^{* *}$ & $-0.77 \pm 1.46$ & 0.058 \\
\hline$\underline{\text { LBM }(\%)}$ & $57.6 \pm 3.8$ & $60.4 \pm 4.3^{* *}$ & $2.81 \pm 2.22$ & $56.9 \pm 3.7$ & $59.4 \pm 3.7^{* *}$ & $2.45 \pm 1.93$ & 0.445 \\
\hline \multirow[t]{2}{*}{ BP systolic (mmHg) } & 131.2 & 119.8 & -11.4 & 128.0 & 119.5 & -8.5 & 0.148 \\
\hline & \pm 17.4 & $\pm 12.8^{* *}$ & \pm 18.8 & \pm 19.7 & $\pm 13.8^{*}$ & \pm 23.5 & \\
\hline$\underline{\text { BP diastolic }(\mathrm{mmHg})}$ & $80.8 \pm 9.6$ & $77.2 \pm 8.6^{*}$ & $-3.6 \pm 11.7$ & $79.8 \pm 9.0$ & $75.5 \pm 8.3^{*}$ & $-4.4 \pm 11.7$ & 0.914 \\
\hline Heart rate $(1 / \min )^{b}$ & $\begin{array}{c}77.0 \pm 10.3 \\
(n=42)\end{array}$ & $75.8 \pm 9.9$ & $-1.2 \pm 8.0$ & $77.8 \pm 10.8$ & $75.8 \pm 11.5$ & $-2.0 \pm 8.9$ & 0.983 \\
\hline
\end{tabular}

abbreviations used: BCM, body cell mass; BFM, body fat mass; BMI, body mass index; BP, blood pressure; C, control group; HC, hip circumference; LBM, lean body mass; MR, meal replacement group; WC, waist circumference; WHR, Waist-to-hip ratio; WHtR, Waist-to-height ratio

${ }^{*} \mathrm{p}<0.05 ;{ }^{* *} \mathrm{p}<0.001$; Wilcoxon-test within groups

ap-value: Mann-Whitney-U-test

${ }^{\mathrm{b}}$ data not available for all women

underreporting. Dietary sodium intake was estimated from $24 \mathrm{~h}$ urinary sodium excretion.

\section{Discussion}

Our results indicate that both weight loss strategies are effective treatment options for overweight women. The goal to achieve a weight loss of more than $5 \%(4.2 \mathrm{~kg}$ of mean body weight at baseline) after 12 weeks was exceeded by at least $1.8 \mathrm{~kg}$ in the MR group but only by $0.6 \mathrm{~kg}$ in the $\mathrm{C}$ group, which is reflected in the significantly increased responder rate of the MR group. These results can be attributed to the preference for convenience foods [20] The weight loss of approximately 5\% achieved in both groups is similar to that reported for preobesity and obesity stage I [14-16,21]. It has been reported that especially time and structure of the nutritional education play an important role in achieving high compliance [14]. Moreover, regular education to achieve an increase in physical activity is necessary, especially for maintaining the body weight [22].
For the evaluation of cardiometabolic risk not only body weight is important. The role of the body fat distribution phenotype has been shown to be even more prominent than that of BMI [23]. Compared to visceral fat, a high proportion of subcutaneous fatty tissue is accompanied by a lower cardiometabolic risk. Therefore, reduction in WC is considered to be more essential than loss of body weight alone, especially in DM2 [24]. Studies have shown that WHtR is the best indicator of cardiovascular risk in different measures of abdominal obesity and that it can be used to assess body composition [25]. In the present study, the significant decrease in WC and WHtR in both groups during dietary intervention suggests that the body fat distribution phenotype has changed. A general cutoff of 0.5 has been suggested for WHtR [26]. However, this value was not achieved in our study population.

A strong association has been demonstrated between WC and plasma TG [27]. After the 12-week dietary intervention a decrease in WC by $6.6 \mathrm{~cm}$ in the MR 
Table 4 Change in the cardiometabolic risk profile in overweight women after dietary intervention

\begin{tabular}{|c|c|c|c|c|c|c|c|}
\hline & \multicolumn{3}{|c|}{$\begin{array}{c}\text { MR }(n=43) \\
n(\%)\end{array}$} & \multicolumn{3}{|c|}{$\begin{array}{c}C(n=44) \\
n(\%)\end{array}$} & \multirow{2}{*}{$\begin{array}{c}\text { MR vs } \\
\mathrm{P}^{\mathrm{b}}\end{array}$} \\
\hline & Baseline & Week 12 & $\mathrm{P}^{\mathrm{a}}$ & Baseline & Week 12 & $\mathrm{P}^{\mathrm{a}}$ & \\
\hline $\begin{array}{l}\text { Weight reduction } \\
>5 \%\end{array}$ & - & $\begin{array}{c}33 \\
(76.7 \%)\end{array}$ & - & - & $\begin{array}{c}22 \\
(50.0 \%)\end{array}$ & - & 0.010 \\
\hline$W C>88 \mathrm{~cm}$ & $\begin{array}{c}31 \\
(72.9 \%)\end{array}$ & $\begin{array}{c}19 \\
(44.2 \%)\end{array}$ & 0.009 & $\begin{array}{c}37 \\
(84.1 \%)\end{array}$ & $\begin{array}{c}24 \\
(54.5 \%)\end{array}$ & 0.003 & 0.429 \\
\hline $\begin{array}{l}\text { BP systolic } \\
\geq 130 \mathrm{mmHg}\end{array}$ & $\begin{array}{c}28 \\
(65.1 \%)\end{array}$ & $\begin{array}{c}15 \\
(34.9 \%)\end{array}$ & 0.005 & $\begin{array}{c}20 \\
(45.5 \%)\end{array}$ & $\begin{array}{c}12 \\
(27.3 \%)\end{array}$ & 0.076 & 0.263 \\
\hline $\begin{array}{l}\text { BP diastolic } \\
\geq 85 \mathrm{mmHg}\end{array}$ & $\begin{array}{c}13 \\
(30.2 \%)\end{array}$ & $\begin{array}{c}9 \\
(20.9 \%)\end{array}$ & 0.323 & $\begin{array}{c}6 \\
(13.6 \%)\end{array}$ & $\begin{array}{c}6 \\
(13.6 \%)\end{array}$ & 1.000 & 0.229 \\
\hline $\mathrm{BP} \geq 130 / 85 \mathrm{mmHg}$ & $\begin{array}{c}12 \\
(27.9 \%)\end{array}$ & $\begin{array}{c}5 \\
(11.6 \%)\end{array}$ & 0.058 & $\begin{array}{c}6 \\
(13.6 \%)\end{array}$ & $\begin{array}{c}5 \\
(11.4 \%)\end{array}$ & 0.747 & 0.439 \\
\hline $\mathrm{TG} \geq 150 \mathrm{mg} / \mathrm{dl}$ & $\begin{array}{c}14 \\
(41.2 \%)^{c}\end{array}$ & $\begin{array}{c}16 \\
(47.1 \%)^{c}\end{array}$ & 0.651 & $\begin{array}{c}15 \\
(44.1 \%)^{c}\end{array}$ & $\begin{array}{c}13 \\
(38.2 \%)^{c}\end{array}$ & 0.647 & 0.897 \\
\hline $\mathrm{HDL}-\mathrm{C}<50 \mathrm{mg} / \mathrm{dl}$ & $\begin{array}{c}11 \\
(32.4 \%)^{c}\end{array}$ & $\begin{array}{c}12 \\
(35.3 \%)^{c}\end{array}$ & 0.808 & $\begin{array}{c}8 \\
(23.5 \%)^{c}\end{array}$ & $\begin{array}{c}11 \\
(32.4 \%)^{c}\end{array}$ & 0.437 & 0.851 \\
\hline $\begin{array}{l}\text { Fasting glucose } \\
\geq 110 \mathrm{mg} / \mathrm{dl}\end{array}$ & $\begin{array}{c}2 \\
(5.9 \%)^{c}\end{array}$ & $\begin{array}{c}2 \\
(5.9 \%)^{c}\end{array}$ & 1.000 & $\begin{array}{c}3 \\
(8.8 \%)^{c}\end{array}$ & $\begin{array}{c}1 \\
(2.9 \%)^{c}\end{array}$ & 0.306 & 0.906 \\
\hline $\begin{array}{l}\text { Hypertriglyceridemic } \\
\text { waist }^{d}\end{array}$ & $\begin{array}{c}12 \\
(35.3 \%)^{c}\end{array}$ & $\begin{array}{c}7 \\
(20.6 \%)^{c}\end{array}$ & 0.194 & $\begin{array}{c}14 \\
(41.2 \%)^{c}\end{array}$ & $\begin{array}{c}7 \\
(20.6)^{c}\end{array}$ & 0.080 & 0.984 \\
\hline $\begin{array}{l}\text { Atherogenic } \\
\text { dyslipidemia }\end{array}$ & $\begin{array}{c}6 \\
(17.6 \%)^{c}\end{array}$ & $\begin{array}{c}7 \\
(20.6 \%)^{c}\end{array}$ & 0.763 & $\begin{array}{c}4 \\
(11.8 \%)^{c}\end{array}$ & $\begin{array}{c}3 \\
(8.8 \%)^{c}\end{array}$ & 0.694 & 0.490 \\
\hline
\end{tabular}

abbreviations used: BP, blood pressure; C, control group; HDL-C, HDL cholesterol; MR, meal replacement group; WC, waist circumference

${ }^{a}$ p-value: chi-square-test within groups

${ }^{b}$-value: chi-square-test in contingency tables

'biochemical analysis with the same method $(n=34)$

${ }^{d}$ hypertriglyceridemic waist, i.e. WC $>88 \mathrm{~cm}$ and TG $\geq 150 \mathrm{mg} / \mathrm{dL}$ [18]

eatherogenic dyslipidemia, i.e. triad of elevated triglycerides, low HDL-C, and small LDL-C particles [3]

group and by $5.5 \mathrm{~cm}$ in the $\mathrm{C}$ group was achieved. Surprisingly, in our study no significant reduction in fasting serum TG and glucose was observed in the present trial.

In our study, a similar reduction of TC and LDL-C was found in both groups, which can be attributed to energy restriction and the resulting weight loss. Although the significant decrease in HDL-C is remarkable, mean HDL-C at baseline and after the 12-week dietary intervention was above the cutoff of $50 \mathrm{mg} / \mathrm{dL}$. It is notable that the number of women with a HDL-C below $50 \mathrm{mg} / \mathrm{dL}$, TG above $150 \mathrm{mg} / \mathrm{dL}$ and atherogenic dyslipidemia, respectively, did not change in both groups. Although several studies found that weight reduction in overweight and obese subjects favorably modifies atherogenic dyslipidemia $[28,29]$, we were unable to confirm these findings. One reason could be the fatty acid composition of the dietary intervention with an insufficient proportion of MUFA and especially long-chain n-3 polyunsaturated fatty acids ( $n-3$ LC PUFA).

Moreover, the 12-week dietary intervention resulted in a significant and similar improvement of systolic and diastolic BP in both groups. However, the number of women with systolic BP $\geq 130 \mathrm{mmHg}$ decreased significantly only in the MR group and the number of women with a BP of $130 / 85 \mathrm{mmHg}$ tended to decrease after 12 weeks.

In the present study, body weight loss resulted in a significant reduction in systolic BP in the study population $(p=0.002)$ (Table 6). This effect depended on the body weight at baseline. The higher the initial body weight, the higher was the reduction in systolic BP and diastolic BP. One $\mathrm{kg}$ of weight loss resulted in a reduction of systolic and diastolic BP by 2.0 and $1.1 \mathrm{mmHg}$, respectively. The effect of weight loss on systolic BP was more pronounced in the $\mathrm{C}$ group and amounted to 3.5 $\mathrm{mmHg}$ per $\mathrm{kg}$ body weight $(\mathrm{p}=0.001)$ as compared to $1.0 \mathrm{mmHg}$ per $\mathrm{kg}$ body weight in the MR group $(\mathrm{p}=$ 0.480). Diastolic BP was similar with $1.7 \mathrm{mmHg}$ per $\mathrm{kg}$ body weight in the $\mathrm{C}$ group $(\mathrm{p}<0.001)$, and $0.4 \mathrm{mmHg}$ in the MR group $(\mathrm{p}=0.545)$.

Apart from the influence of weight loss on the systolic blood pressure, dietary sodium intake, estimated from $24 \mathrm{~h}$ urinary sodium excretion, seemed to exert different effects on both groups. No convincing association was found between systolic BP and serum cortisol and between systolic BP and sodium intake (Table 6). Body cell mass (BCM) and lean body mass (LBM) decreased in both groups, while the percentage of BCM of body weight increased more in the MR group than in the $C$ 
Table 5 Clinical chemistry and biochemical characteristics in overweight women at baseline and after dietary intervention

\begin{tabular}{|c|c|c|c|c|c|c|c|}
\hline & \multicolumn{3}{|c|}{ MR $(n=34)^{\text {a }}$ Mean $\pm S D$} & \multicolumn{3}{|c|}{$C(n=34)^{a}$ Mean $\pm S D$} & \multirow{2}{*}{$\frac{\text { MR vs C }}{\mathrm{P}^{\mathrm{b}}}$} \\
\hline & Baseline & Week 12 & Difference & Baseline & Week 12 & Difference & \\
\hline Glucose (mg/dL) & $91.8 \pm 13.7$ & $92.4 \pm 10.9$ & $0.63 \pm 10.94$ & $90.7 \pm 14.3$ & $88.1 \pm 13.1$ & $-2.66 \pm 10.74$ & 0.315 \\
\hline $\mathrm{HbA1c}(\%)$ & $5.54 \pm 0.63$ & $5.49 \pm 0.47$ & $-0.05 \pm 0.64$ & $5.63 \pm 0.51$ & $5.46 \pm 0.48$ & $-0.16 \pm 0.61$ & 0.201 \\
\hline $\mathrm{TC}(\mathrm{mg} / \mathrm{dL})$ & $241.2 \pm 53.1$ & $224.4 \pm 53.2^{*}$ & $-16.7 \pm 33.7$ & $241.5 \pm 34.3$ & $230.3 \pm 40.9^{*}$ & $-11.2 \pm 25.9$ & 0.556 \\
\hline $\mathrm{HDL}-\mathrm{C}(\mathrm{mg} / \mathrm{dL})$ & $59.1 \pm 16.1$ & $55.3 \pm 14.1^{* *}$ & $-3.7 \pm 6.2$ & $59.2 \pm 11.5$ & $55.7 \pm 10.9^{*}$ & $-3.5 \pm 5.2$ & 0.864 \\
\hline $\mathrm{LDL}-\mathrm{C}(\mathrm{mg} / \mathrm{dL})$ & $157.0 \pm 39.7$ & $144.0 \pm 38.4^{* *}$ & $-13.0 \pm 18.2$ & $161.4 \pm 24.2$ & $152.3 \pm 30.8^{*}$ & $-9.1 \pm 18.7$ & 0.647 \\
\hline $\mathrm{TG}(\mathrm{mg} / \mathrm{dL})$ & $186.4 \pm 145.6$ & $161.1 \pm 108.0$ & $-25.3 \pm 110.4$ & $152.5 \pm 83.8$ & $141.6 \pm 66.1$ & $-10.9 \pm 52.9$ & 0.861 \\
\hline $\mathrm{TG} / \mathrm{HDL}-\mathrm{C}$ & $3.59 \pm 3.55$ & $3.19 \pm 2.49$ & $-0.40 \pm 2.44$ & $2.71 \pm 1.66$ & $2.62 \pm 1.37$ & $-0.09 \pm 0.96$ & 0.880 \\
\hline LDL-C/HLD-C & $2.81 \pm 0.86$ & $2.73 \pm 0.86$ & $-0.08 \pm 0.33$ & $2.81 \pm 0.63$ & $2.79 \pm 0.68$ & $-0.02 \pm 0.33$ & 0.539 \\
\hline$\overline{\mathrm{GGT}}(\mathrm{U} / \mathrm{L})$ & $33.5 \pm 28.8$ & $27.8 \pm 20.1$ & $-5.72 \pm 12.91^{*}$ & $27.9 \pm 13.3$ & $24.0 \pm 10.6$ & $-3.85 \pm 4.92^{* *}$ & 0.759 \\
\hline Uric acid (mg/dL) & $4.82 \pm 1.18$ & $4.59 \pm 0.94$ & $-0.23 \pm 0.70$ & $4.86 \pm 1.01$ & $4.75 \pm 0.97$ & $0.11 \pm 0.66$ & 0.384 \\
\hline $\begin{array}{l}\text { Homocysteine } \\
(\mu \mathrm{mol} / \mathrm{L})\end{array}$ & $11.7 \pm 4.1$ & $11.0 \pm 2.7$ & $-0.63 \pm 2.66$ & $10.3 \pm 2.0$ & $11.7 \pm 2.7^{*}$ & $1.36 \pm 2.65$ & 0.007 \\
\hline Folic acid $(\mu \mathrm{g} / \mathrm{L})$ & $10.6 \pm 4.9$ & $15.2 \pm 5.8^{* *}$ & $4.62 \pm 5.74$ & $11.1 \pm 4.3$ & $12.3 \pm 7.2$ & $1.17 \pm 6.28$ & 0.005 \\
\hline GFR $\left(\mathrm{mL} / \mathrm{min} / 1.73 \mathrm{~m}^{2}\right)$ & $73.6 \pm 12.0$ & $73.3 \pm 12.1$ & $-0.24 \pm 6.50$ & $74.8 \pm 8.9$ & $72.5 \pm 8.8$ & $-2.27 \pm 6.10$ & 0.202 \\
\hline$\overline{\mathrm{TAC}}(\mu \mathrm{mol} / \mathrm{L})$ & $266.2 \pm 30.8$ & $276.6 \pm 38.4$ & $10.4 \pm 45.6$ & $280.9 \pm 43.0$ & $282.2 \pm 45.7$ & $1.3 \pm 48.5$ & 0.210 \\
\hline Cortisol (nmol/L) & $424.3 \pm 142.5$ & $532.1 \pm 179.6$ & $107.8 \pm 145.6$ & $387.2 \pm 164.6$ & $477.4 \pm 140.9$ & $90.2 \pm 176.0$ & 0.826 \\
\hline TAC/Cortisol $\left(10^{3}\right)$ & $0.70 \pm 0.27$ & $0.58 \pm 0.20$ & $-0.12 \pm 0.27$ & $0.89 \pm 0.49$ & $0.65 \pm 0.25$ & $-0.24 \pm 0.41$ & 0.498 \\
\hline $\bar{U}$-sodium $(\mathrm{mmol} / 24 \mathrm{~h})^{c}$ & $162.2 \pm 64.5$ & $158.2 \pm 94,1$ & $-4.0 \pm 118.0$ & $158.3 \pm 68.1$ & $170.8 \pm 81.2$ & $12.5 \pm 82.9$ & 0.283 \\
\hline
\end{tabular}

abbreviations used: GFR, glomerular filtration rate; GGT, gamma-glutamyltransferase; HbA1c, glycated haemoglobin; HDL-C, HDL cholesterol; LDL-C, LDL cholesterol; TAC, total antioxidative capacity; TC, total cholesterol; TG, triglycerides; U-sodium, urinary sodium

abiochemical measurements with the same method

${ }^{b} \mathrm{p}$-value: Mann-Whitney-U-test; Wilcoxon-test within groups: ${ }^{*} \mathrm{p}<0.05$; ${ }^{*} \mathrm{p}<0.001$

$c_{n}=26$ in the MR group and $n=28$ in the $C$ group

group. The higher increase in the difference in absolute $\mathrm{BCM}$ in the MR group versus $\mathrm{C}$ group resulted in a reduction in systolic $\mathrm{BP}$, whereas $\mathrm{BCM}$ affected systolic $\mathrm{BP}$ in the $\mathrm{C}$ group only via weight reduction (Table 6 and 7). The different changes in body composition and the different impact of body weight are reflected in nonBCM and BCM. The result from the $\mathrm{C}$ group shows

Table 6 Systolic blood pressure depending on body weight, sodium intake and serum cortisol (age-adjusted)

\begin{tabular}{lccc}
\hline Body weight & & & \\
\hline Group & Difference & RC B & P \\
C $(n=34)$ & $-5.0 \pm 3.5$ & 3.516 & 0.001 \\
MR $(n=33)$ & $-6.6 \pm 2.6$ & 1.028 & 0.480 \\
\hline Urinary sodium & & & \\
\hline Group & Difference & RC B & P \\
C $(n=34)$ & $3.5 \pm 70.6$ & -0.051 & 0.383 \\
MR $(n=33)$ & $-29.7 \pm 86.7$ & 0.068 & 0.106 \\
\hline Serum cortisol & & & \\
\hline Group & Difference & RC B & P \\
C $(n=34)$ & $95.2 \pm 164.6$ & 0.041 & 0.105 \\
MR $(n=33)$ & $118.7 \pm 159.1$ & -0.015 & 0.515 \\
\hline
\end{tabular}

abbreviations used: $C$, control group; $M R$, meal replacement group; RC B, regression coefficient $B$ that non-BCM is the dominant factor for systolic BP reduction, while $\mathrm{BCM}$ was found to be the major factor in the MR group. The systolic BP decreased to a similar extent in both groups despite different influencing variables.

GGT is the enzyme responsible for initiating extracellular catabolism of glutathione [30]. Increased GGT activity may be a response to oxidative stress, which can increase the transport of glutathione precursors into cells $[30,31]$ and is involved in the generation of reactive

Table 7 Systolic blood pressure depending on BCM and non-BCM (age-adjusted)

\begin{tabular}{lccc}
\hline Group & $\begin{array}{c}\mathbf{P} \\
\text { ANCOVA }\end{array}$ & dnon-BCM & $\mathbf{d B C M}$ \\
\hline Total & 0.005 & 2.257 & 0.135 \\
& & $(0.7-3.8)$ & $(-4.8-5.1)$ \\
& & 0.004 & 0.957 \\
\hline $\mathrm{C}$ & 0.013 & 2.765 & 3.226 \\
& & $(0.5-5.0)$ & $(-4.0-10.4)$ \\
& & 0.018 & 0.372 \\
\hline MR & 0.218 & 1.231 & -4.689 \\
& & $(-1.0-3.5)$ & $(-11.9-2.6)$ \\
& & 0.278 & 0.198 \\
\hline
\end{tabular}

abbreviations used: BCM, body cell mass; $C$, control group; d, difference; $M R$, meal replacement group 
oxygen species [31]. Therefore, it has been suggested that higher GGT levels are associated with an increased risk for the development of hypertension [32]. In our study, we found a significant reduction in GGT activity in both groups.

Evidence suggests that reactive oxygen species are fundamentally involved in hyperhomocysteinemia, which, together with a low folate status, is a major risk factor for atherosclerosis [33]. In the present study, a significant higher serum homocysteine was found after the 12week dietary intervention in the $\mathrm{C}$ group when compared to the MR group. This result was probably due to a better folate status through increased intake with the $M R$, as demonstrated by the significant increase in serum folic acid in the MR group.

In conclusion, both groups exhibited an effective weight loss. Compliance was higher in the MR group than in the $\mathrm{C}$ group as demonstrated by the higher responder rate in the MR (77\%) than in the $C$ group (50\%). Cardiometabolic risk was positively affected mainly through the decrease in BP, TC and LDL-C, whereas other risk factors were not affected by the 12 week dietary intervention. Systolic BP decreased to a similar extent in both groups despite different influencing variables. The significant lower serum homocysteine and higher folic acid after the 12-week dietary intervention in the MR group was probably due to a better folate status through increased intake with the MR. Cardiometabolic risk profile improved only partly in both groups.

\begin{abstract}
Author details
'Bonn Education Association for Dietetics r. A., Fürst-Pückler-Str. 44, D-50935 Cologne, Germany. ${ }^{2}$ Department of Internal Medicine III, University Hospital, RWTH, Pauwelsstraße 44, D-52074 Aachen, Germany. ${ }^{3}$ Ambulant Centre for Nutrition Education, Frankfurt am Main, Schweizer Straße 47, D- 60594, Frankfurt/M, Germany. ${ }^{4}$ Medicine and Service Ltd, Department of Biostatistics, Boettcherstr. 10, D-09117 Chemnitz, Germany. ${ }^{5}$ B-Vital, Ambulant Centre for Nutrition Education, Elsterwerdaer Platz 1, D-12683 Berlin, Germany. ${ }^{6}$ Department of Nutrition and Food Sciences, Nutritional Physiology, University of Bonn, Endenicher Allee 11-13, AVZ1, D-53115 BonnEndenich, Germany. ${ }^{7}$ Medical Nutrition Science, Department of Urology, University of Bonn, Sigmund-Freud-Straße 25, D-53105 Bonn, Germany.
\end{abstract}

\section{Authors' contributions}

CM was the scientific project manager and acted as an expert on metabolic syndrome. ML conducted the study (supervisor). AFV and SS were responsible for patient inclusion and conducted the study. RS was responsible for the study design and contributed to the interpretation of the data. NB conducted the statistical analysis. CM, RS, BA and AFV constituted the writing group and prepared the paper. ML and PS revised the manuscript. This study was supported in part by a research grant from FormMed HealthCare AG, Frankfurt, Germany. ML is CEO, CM is a consultant and AFV was an employee of FormMed HealthCare AG, Frankfurt, Germany. All authors contributed to the final version of the paper and gave their approval for publication of the final version.

\section{Competing interests}

The authors declare that they have no competing interests.
Received: 27 June 2011 Accepted: 22 September 2011

Published: 22 September 2011

\section{References}

1. Bray GA: Medical consequences of obesity. J Clin Endocrinol Metab 2004 89:2583-2589.

2. Després JP, Lemieux I, Bergeron J, Pibarot P, Mathieu P, Larose E, RodésCabau J, Bertrand OF, Poirier P: Abdominal obesity and the metabolic syndrome: contribution to global cardio-metabolic risk. Arterioscler Thromb Vasc Biol 2008, 28:1039-1049.

3. Third report of the National Cholesterol Education Program (NCEP): Expert Panel on Detection, Evaluation, and Treatment of High Blood Cholesterol in Adults (Adult Treatment Panel III) Final Report. Circulation 2002, 106:3143-3421

4. Kahn HS, Valdez R: Metabolic risks identified by the combination of enlarged waist and elevated triacylglycerol concentration. Am J Clin Nutr 2003, 78:928-934.

5. Bray GA, Jablonski KA, Fujimoto WY, Barrett-Connor E, Haffner S, Hanson RL, Hill JO, Hubbard V, Kriska A, Stamm E, Pi-Sunyer FX, Diabetes Prevention Program Research Group: Relation of central adiposity and body mass index to the development of diabetes in the Diabetes Prevention Program. Am J Clin Nutr 2008, 87:1212-1218.

6. Demerath EW, Reed D, Rogers N, Sun SS, Lee M, Choh AC, Couch W, Czerwinski SA, Chumlea WC, Siervogel RM, Towne B: Visceral adiposity and its anatomical distribution as predictors of the metabolic syndrome and cardiometabolic risk factor levels. Am J Clin Nutr 2008, 88:1263-1271.

7. Jacobs EJ, Newton CC, Wang Y, Patel AV, McCullough ML, Campbell PT, Thun MJ, Gapstur SM: Waist circumference and all-cause mortality in a large US cohort. Arch Intern Med 2010, 170:1293-1301.

8. Snijder MB, Dekker JM, Visser M, Bouter LM, Stehouwer CDA, Kostense PJ, Yudkin JS, Heine RJ, Nijpels G, Seidell JC: Association of hip and thigh circumferences independent of waist circumference with the incidence of type 2 diabetes: the Hoorn Study. Am J Clin Nutr 2003, 77:1192-1197.

9. Park HS, Lee K: Greater beneficial effects of visceral fat reduction compared with subcutaneous fat reduction on parameters of the metabolic syndrome: a study of weight reduction programmes in subjects with visceral and subcutaneous obesity. Diabet Med 2005, 22:266-272.

10. Lee JW, Lee HR, Shim JY, Im JA, Lee DC: Abdominal visceral fat reduction is associated with favorable changes of serum retinol binding protein-4 in nondiabetic subjects. Endocr J 2008, 55:811-818.

11. Björntorp P: Do stress reactions cause abdominal obesity and comorbidities? Obesity Rev 2001, 2:73-86.

12. Ard JD, Coffman CJ, Lin PH, Svetkey LP: One-year follow-up study of blood pressure and dietary patterns in dietary approaches to stop hypertension (DASH)-sodium participants. Am J Hypertens 2004 17:1156-1162.

13. Taubert D, Roesen R, Lehmann C, Jung N, Schömig E: Effects of low habitual cocoa intake on blood pressure and bioactive nitric oxide: a randomized controlled trial. JAMA 2007, 298:49-60.

14. Ashley JM, St Jeor ST, Perumean-Chaney S, Schrage J, Bovee V: Meal replacements in weight intervention. Obes Res 2001, 9(Suppl 4):312S-320S

15. Flechtner-Mors M, Ditschuneit HH, Johnson TD, Suchard MA, Adler G: Metabolic and weight loss effects of long-term dietary intervention in obese patients: four-year results. Obes Res 2000, 8:399-402.

16. Heymsfield SB, van Mierlo CAJ, van der Knaap HCM, Heo M, Frier HI: Weight management using a meal replacement strategy: meta and pooling analysis from six studies. Int J Obes 2003, 27:537-549.

17. Kyle UG, Bosaeus I, De Lorenzo AD, Deurenberg P, Elia M, Gómez JM, Heitmann BL, Kent-Smith L, Melchior JC, Pirlich M, Scharfetter H, Schols AMWJ, Pichard C: Bioelectrical impedance analysis-part II: utilization in clinical practice. Clin Nutr 2004, 23:1430-1453.

18. LaMonte MJ, Ainsworth BE, DuBose KD, Grandjean PW, Davis PG, Yanowitz FG, Durstine JL: The hypertriglyceridemic waist phenotype among women. Atherosclerosis 2003, 171:123-130.

19. Frankenfield DC, Muth ER, Rowe WA: The Harris-Benedict studies of human basal metabolism: history and limitations. J Am Diet Assoc 1998, 98:439-445.

20. Noakes M, Foster PR, Keogh JB, Clifton PM: Meal replacements are as effective as structured weight-loss diets for treating obesity in adults with features of metabolic syndrome. J Nutr 2004, 134:1894-1899. 
21. König D, Deibert P, Frey I, Landmann U, Berg A: Effect of meal replacement on metabolic risk factors in overweight and obese subjects. Ann Nutr Metab 2008, 52:74-78

22. Klein S, Sheard NF, Pi-Sunyer X, Daly A, Wylie-Rosett J, Kulkarni K, Clark NG Weight management through lifestyle modification for the prevention and management of type 2 diabetes: rationale and strategies: A statement of the American Diabetes Association, the North American Association for the Study of Obesity, and the American Society for Clinical Nutrition. Diabetes Care 2004, 27:2067-2073.

23. Lofgren I, Herron K, Zern T, West K, Patalay M, Shachter NS, Koo SI, Fernandez ML: Waist circumference is a better predictor than body mass index of coronary heart disease risk in overweight premenopausal women. J Nutr 2004, 134:1071-1076.

24. Tankó LB, Bagger YZ, Qin G, Alexandersen P, Larsen PJ, Christiansen C. Enlarged waist combined with elevated triglycerides is a strong predictor of accelerated atherogenesis and related cardiovascular mortality in postmenopausal women. Circulation 2005, 111:1883-1890.

25. Schneider HJ, Friedrich N, Klotsche J, Pieper L, Nauck M, John U, Dörr M, Felix S, Lehnert H, Pittrow D, Silber S, Völzke H, Stalla GK, Wallaschofski H, Wittchen $\mathrm{HU}$ : The predictive value of different measures of obesity for incident cardiovascular events and mortality. I Clin Endocrinol Metab 2010, 95:1777-1785.

26. Ashwell M, Hsieh SD: Six reasons why the waist-to-height ratio is a rapid and effective global indicator for health risks of obesity and how its use could simplify the international public health message on obesity. Int $J$ Food Sci Nutr 2005, 56:303-307.

27. Lemieux I, Pascot A, Couillard C, Lamarche B, Tchernof A, Alméras N, Bergeron J, Gaudet D, Tremblay G, Prud'homme D, Nadeau A, Despres JP: Hypertriglyceridemic waist: A marker of the atherogenic metabolic triad (hyperinsulinemia; hyperapolipoprotein B; small, dense LDL) in men? Circulation 2000, 102:179-184.

28. National Institutes of Health: Clinical guidelines on the identification, evaluation, and treatment of overweight and obesity in adults - the evidence report. NIH Pub No 98-4083. Bethesda, MD: National Heart, Lung and Blood Institute; 1998, 228.

29. National Institutes of Health: Clinical guidelines on the identification evaluation, and treatment of overweight and obesity in adults - the evidence report. Obesity Res 1998, 6(Suppl 2):51-209.

30. Whitfield JB: Gamma glutamyl transferase. Crit Rev Clin Lab Sci 2001, 38:263-355.

31. Lee $D H$, Blomhoff $R$, Jacobs $D R$ : Is serum gamma glutamyltransferase a marker of oxidative stress? Free Radic Res 2004, 38:535-539.

32. Sabanayagam C, Shankar A, Li J, Pollard C, Ducatman A: Serum gammaglutamyl transferase level and diabetes mellitus among US adults. Eur $J$ Epidemiol 2009, 24:369-373.

33. Stanger $\mathrm{O}$, Weger M: Interactions of homocysteine, nitric oxide, folate and radicals in the progressively damaged endothelium. Clin Chem Lab Med 2003, 41:1444-1454.

doi:10.1186/1743-7075-8-64

Cite this article as: Metzner et al.: Effect of a conventional energyrestricted modified diet with or without meal replacement on weight loss and cardiometabolic risk profile in overweight women. Nutrition \& Metabolism 2011 8:64.

\section{Submit your next manuscript to BioMed Central and take full advantage of:}

- Convenient online submission

- Thorough peer review

- No space constraints or color figure charges

- Immediate publication on acceptance

- Inclusion in PubMed, CAS, Scopus and Google Scholar

- Research which is freely available for redistribution

Submit your manuscript at www.biomedcentral.com/submit 